DOI: $10.22616 /$ REEP.2020.053

\title{
Goals of the Dialogue of Students Career Guidance in Vocational Secondary Education
}

\author{
Inita Soika Mg.paed. \\ Latvia University of Life Sciences and Technologies, Latvia \\ inita.soika@1lu.lv
}

\begin{abstract}
Nowadays dialogue is recognized as one of the main tools for individual career development and life designing because encouraging reflection and decision-making. The intent of the dialogue has always been aimed at understanding. The main goal of dialogue of students' career guidance in vocational secondary education is to build mutual dialogical interaction among the students, teachers, employers, career professionals, and school leadership. Such understanding provides the basis for a common set of goals and direction on how to help students to explore the labour market, learn to plan their career and make the right decisions in work-based learning. The aim of the study was to assess the findings of theoretical and empirical cognitions and to analyse the goals of dialogue from several points of view in students' career guidance: first of all, the model of the fields of conversations of W. Isaacs is used to reveal how the dialogue is developing; secondly, - the stages of career guidance and, thirdly, work-based learning for understanding the educational context of students' career development and life designing in vocational secondary education. A theoretical and empirical study was conducted. The empirical research was based on the methods of survey and experience reflection. There was used a survey questionnaire. The survey sample included 96 first to fourth-year students from six secondary vocational education schools of different regions of Latvia. During data processing the obtained results are statistically significant. Results show that only one-third of the respondents have established a dialogue with the career guidance stakeholders of secondary vocational education. Goal setting and achievement in dialogue development enables all career guidance professionals to understand, what support is needed for students of vocational education training schools. The hierarchical and successive nature of the goals in the development of the dialogue highlights the need for cooperation and common understanding among the persons involved in the development of students' careers.
\end{abstract}

Keywords: dialogue, goals, objectives, work-based learning, career guidance.

\section{Introduction}

Dialogue always causes change because occur mutual learning. This has been recognized by several dialogues' researchers in their studies (Bohm, 2004; Habermas, 2015; Peavy, 2004). The purpose of the dialogue is to transform and improve the current situation, which has been facilitated by the ability of involved persons to agree on a common understanding of the problem, common goals and actions. For all that, the daily situation of career guidance in vocational secondary education shows that, due to different circumstances, there is no deliberative dialogue between students and organizers of career guidance - teachers, school management and potential employers. Engaging in dialogue indicates persons' awareness and interest in solving problems. In this way, they acquire new knowledge, experience, and attitude. It is a learning process in which individuals are constantly and responsibly exploring themselves, nature and society. This process is facilitated by social interactions and the responsiveness of the surrounding community (Pedagogijas terminu skaidrojošā..., 2000). It can also be applied to the dialogue on support for the career development of students in vocational secondary education, where the acquisition of a profession takes place in work-based learning (ESF projekts..., 2019).

In essence, the goal is the desired outcome of the action, which is sought to achieve, and which gives direction to a particular action and expresses its meaning. The goal is the basic tool that underpins all planning and strategic activities. Precisely defined goals are the rationale and result of any action. They must be specific, measurable, achievable, realistic and limited in time (Doran, 1981).

Goals can be strategic, closer and concrete (Pedagoǵijas terminu skaidrojošā..., 2000). Strategic goals are comprehensive and general. They indicate direction and desired result, provided the person or group of people and accompanied by all the efforts to achieve it. In addition to the desired result, such a generalized goal includes plans and commitments that will ensure that the goal is fruitful. The closest 
goals describe the turning points in the overall progress towards the strategic goal. The specific objectives are targets that result from a specific quantitative or qualitative result (Pedagogijas terminu skaidrojošā..., 2000). The specific objectives are what an individual or group plan to do or achieve within a given time period with available resources and allows them to feel more motivated when they are achieved and when they are approaching strategic goal that at first may seem very difficult to reach. Such a hierarchical breakdown of goals is also used in this study because dialogue as a process involves different types of conversations that contribute to achieving the desired outcome in the students' career guidance. Every goal, including the goals of dialogue, has an impact on both the individual and the processes in the environment. The strategic goal of the dialogue is to promote cooperation between persons involved in students' career guidance of secondary vocational education in order to advance their career development and life designing.

The aim of the study is to explore and evaluate goals of the dialogue in students' career guidance of secondary vocational education.

\section{Methodology}

The goals of the dialogue in the career guidance of students are described based on the stages of career development in vocational secondary education. The study sets out the goals and objectives of the dialogue, integrating them into the W. Isaacs' model of conversational fields (Isaacs, 1999). This model shows how dialogue is developed through different types of conversation and thinking.

The following research questions were raised in order to assess the goals of the dialogue on student career guidance in vocational secondary education: 1) what goals are needed to develop in the dialogue of student' career guidance in vocational secondary education? 2) What are the benefits of achieving the goals of the dialogue on student career guidance in vocational secondary education?

The methods of the research: 1) studies, analysis and evaluation of scientific literature; 2) reflection on experience; 3) questionnaire of 96 first to fourth-year students from six secondary vocational education schools of different regions of Latvia participated in the survey. A total of 1487 answers of students were evaluated. The survey questions were chosen according to the traits of the conversational fields of W. Isaacs' model (Figure1). Student responses indicated which stage of dialogue they are in. Student confidence was assessed as one of the basic conditions for dialogue. Based on the characteristics of each field of conversation and the educational context in which the student's career guidance takes place, it was possible to determine what the goals of the dialogue are necessary for the students' career development and life designing.

\section{Results and Discussion}

Goals of the dialogue points to the benefits those are associated with the expectations that will be filled when the goals will be achieved. Building of confidence among participants is one of the key benefits of moving towards the goals of dialogue. It is the basis for mutual cooperation, conflict resolution, promoting reflection, and inspiring new, creative ideas and actions. The four conversations' fields that define the goals of the dialogue are described below. Goals of dialogue are shown in Figure 1. Survey data reveal students' views on whether they confide to persons involved in career guidance - teachers, peers, career counsellors, school leaders, and practice' mentors in enterprises.

Twenty-five percent of the answers given by students show that they are not ready to talk about their future intentions with persons involved in career guidance because they are not sure whether they currently acquire the right profession; they don't know what they really want; they are afraid to make a mistake in the presence of others; they do not trust own future dreams and aspirations to others (Isaacs, 1999). This is the first field of conversation in which the downloading of dialog takes place. In the case of a career dialogue, the concept of downloading is to be understood as sending information from major objects to smaller individual units. It may be informed what students receive from persons involved in providing his or her career guidance. Based on the findings of W. Isaacs (Isaacs, 1999), the first field of conversation is characterized by unstable and volatile communication. There is mutual distrust and extremely low energy of dialogue because individuals have quite different expectations. They don't disclose what they really think and feel, but they talk about what the others want to hear. Only a single monologue of 
individuals gives the opportunity to move on to the debate others (Isaacs, 1999). Based on the characteristics of this field, it can be assumed that the goal of the dialogue is to animate the conversation and form the basis for the development of dialogue. D.R. Traum and J.F. Allen (Traum, Allen, 1992) write that it means inviting various persons to start tackling acute issues. It means to encourage students and involved persons in conversation. The objectives of this field of conversation are two: firstly, to be polite and to refer to a formal conversation; secondly, to get information from the persons involved in the dialogue in order to understand the nature of the communication. The benefits of the involved persons in achieving the goal of the dialogue in the first field are as follows: as seen, heard and experienced, they are aware that collaboration can contribute student' career development and life designing (Figure 1).

Eighteen percent of students' statements suggest that there has been a desire to express their views on issues related to their career and future intentions. It is - debate - the second field of conversations others (Isaacs, 1999), where students begin to dare to say what they think, even if it is not like the others, and each maintains own position; but if the person is convinced, he can also change his mind. This means that there are debates with both him and others. They begin to listen to others (Isaacs, 1999). Participants of the conversation start adapting to a particular environment. They have a desire to take their position because everyone has an opinion, but they are more concerned about how to express their opinions than to challenge the opinions of others. It does not help to solve the problem, because it does not create confidence and expectations that are essential for stimulating reflection. P. Senge (Senge, 2006) and C.O. Scharmer (Scharmer, 2016) emphasizes that debate forms a space of conversation for a new agreement. But persons have to feel confident, so that to change their view. D. Boom (Bohm, 2004) recommends helping them stop expressing their opinions. It means that the individual should receive timely, quality support that helps to move to space of collective reflection (Isaacs, 1999). When the participants of the conversation guess that the problem has to be solved, a secure dialogue space is emerging. So, the goal of the secondary field of conversations is to create and develop a debate that encourages thoughtful dialogue (Figure 1). It means that the objective of involved persons is to explore the differences of opinion and find out what is each person's participation in the researched issue. Based on common values, in this way overcomes the disagreements that hinder the development of a coherent flow of thoughts and actions. The benefits of involved persons are as follows: firstly, the students themselves guess that their issues of career developing need to be addressed; secondly, both students and involved persons are beginning to discover what they really think and feel; thirdly, engaging in debates with self and others makes aware of the different points of view; fourthly, - learn to think about the wrong processes and look for new solutions; fifthly, there is a desire to continue the dialogue. P. Senge (Senge, 2006) and C.O. Scharmer (Scharmer, 2016) believes that the second field is most complex on the way to a common understanding. But, when the participants begin to really understand the need for mutual communication, they try to invest a variety of resources in the development of dialogue in order to avoid polarization of opinions and end the difficulties. Debates can develop from different types of conversation. D.N. Walton and E.C.W. Krabbe (Walton, Krabbe, 1995) note that conversations are the ones that confirm the need for cooperation among the parties involved in the dialogue. The main goal of conversations is to reach an agreement, but goal of the participants is to get the best and most desirable result for themselves. Based on findings of D.N. Walton and E.C.W. Krabbe (Walton, Krabbe, 1995), one can assume that the second field of conversation fits well: persuasion dialogue or critical discussion - because each participant's objective is to convince each other, gradually revealing own position in order to understand whether is necessary to develop further cooperation; information-seeking dialogue, whose objectives are to acquire, transfer and demonstrate personal knowledge as well as eristic discussion, whose objective is to explore the temporary relationship. However, the participant's goal can also be to ignore others when he/she no longer continues to engage in dialogue. Here deliberative dialogue fits well (London, 2005) - a form of discussion where different options are considered before committing themselves to a certain way. D. Hitchcock, P. Mcburney and S. Parsons (Hitchcock, Mcburney, Parsons, 2001) write that it is essential for all parties involved in the dialogue to find the best course of action in which the issue under the discussion is "What should we do?", because goal is not so much to solve problem, but explore the most promising ways to act and decide what to do. Although deliberative dialogue cannot create consensus, it can still create collective insights and judgments that reflect the group's overall thinking. Such type of dialogue is necessary for activities related to the future. 


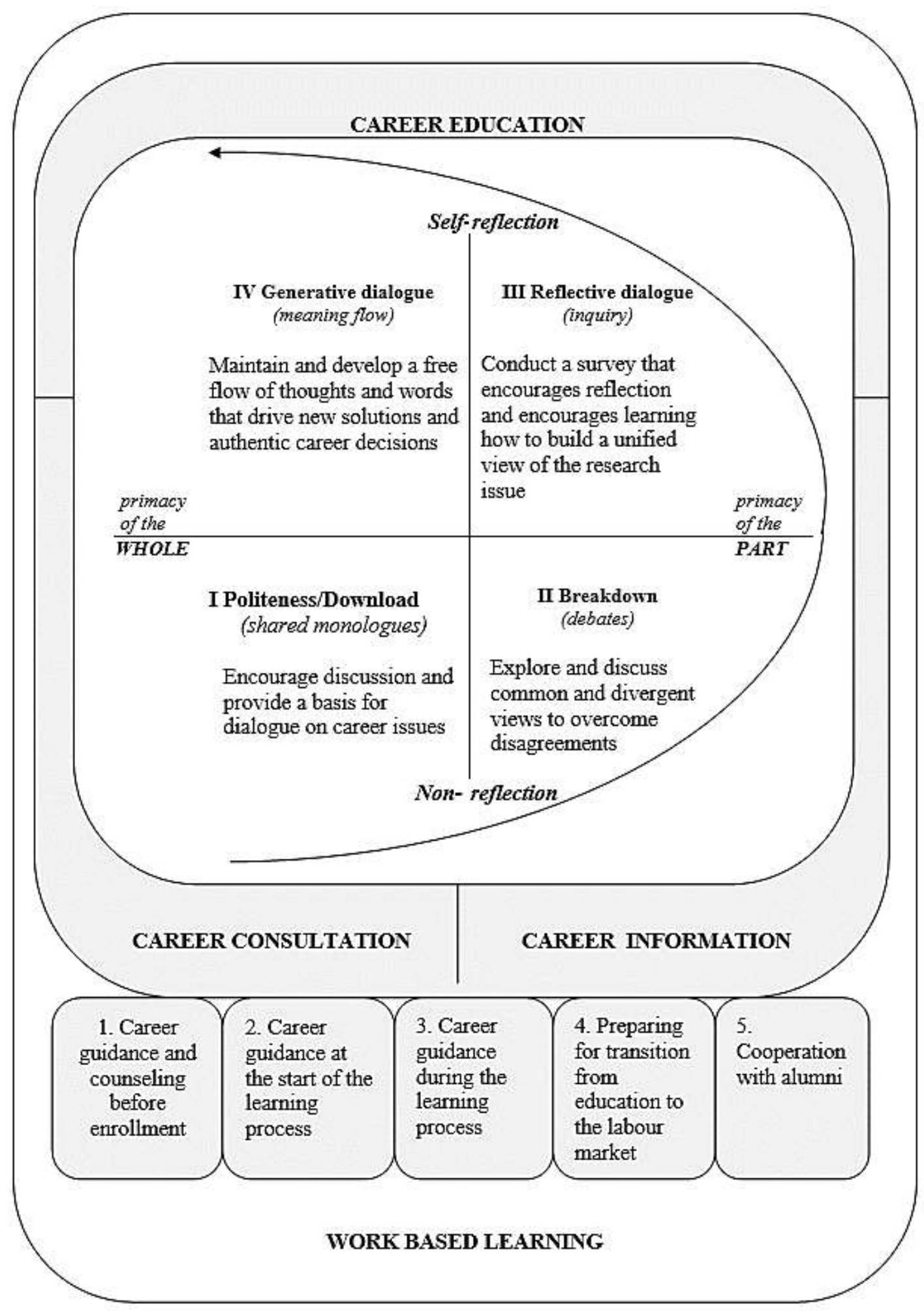

Figure 1. Goals of the dialogue of students' career guidance in the work-based learning.

Twenty-two percent of students' answers indicate that when dealing with their careers, they start to ponder and understand why they do something. They have a curiosity and desire to learn more about their profession, and to study their own assumptions and the nature of their behaviour; they can safely talk about their future plans and justify their thoughts and beliefs. This is the third field of conversations, in which reflective dialogue takes place (Isaacs, 1999). Based on the cognitions of P. Senge (Senge, 2006) and C.O. Scharmer (Scharmer, 2016) about the processes in the third field of conversation, can assume that goal of the dialogue is to conduct a questioning that encourages reflection and provides an opportunity to form a unified view of the subject under investigation. 
D.N. Walton and E.C.W. Krabbe (Walton, Krabbe, 1995) points out that inquiry among participants of dialogue teach each other to get new experience and knowledge, which gives more opportunities to come to an agreement. It follows that the goal of a third conversational field is to learn to build a single, meaningful perspective on the issue under consideration (Figure 1). It finally shows a stable and secure environment for dialogue, in which the participants are ready to recognize the things they do not know. They begin to listen and understand the different views and seek a common framework of principles for further development of the dialogue. They are ready to test their personal bias, as well as change their opinion if they are confronted with convincing and substantiated information (Isaacs, 1999). There are several benefits for the involved persons: their understanding becomes clearer, because they are influenced by the judgments of others and reflected upon; they are able to think from different perspectives; increasing the ability to talk across different points of view, until to begin to speak and listen in a way that allows to connect different points of view and to create a new unified whole view; they start to focus thinking on qualitative solutions of the problem. This would encourage an appreciation of the values and interests of the dialogue' participants in the in order to facilitate the students' right career choices (Racene, Dislere, 2019).

In turn, thirty-four percent or 506 students' responses indicate features of creative dialogue - a fourth field of conversation. Based on the cognitions of W. Isaacs (Isaacs, 1999), students trust the people involved in the dialogue when dealing with their career and future intentions, because together they are looking for the best solutions. Opinions of others are important to them, even if they are different. They listen carefully to what others say and try not to criticize and discuss; they enjoy the silence when occur thinking about a common issue and coming to a completely new solution; they see and feel that their thoughts and questions are important not only to themselves but also to those who they trust (Isaacs, 1999). There is a commitment to active listening and a collective and meaningful search for problem-solving, in which any expression of judgment is halted. There is mutual respect here; each participant comes up with his or her authentic voice (Scharmer, 2016; Walton, Krabbe, 1995). The goal of the dialogue is the free flow of thoughts and words, which leads to new solutions. The objectives of this field of conversation are fellows: to understand things holistically. Participants of dialogue are self-motivated to create new rules for maintaining and developing harmonious mutual cooperation. It means to find and explore the most relevant options for action. The benefits of the involved persons are as follows: they are fully aware of their participation in the dialogue and are truly interested in resolving issues. They discover that what is being said affects other participants; they are aware that the group's mood and climate change from the goals and responsibilities of each participant to the team's overall goals and responsibilities.

It can be concluded from the results of the study that $1 / 3$ or 506 of the students' answers show that they have established a reliable mutual dialogue with the persons involved in career guidance. They are in the field of creative dialogue. However, 1/4 or 378 student responses show that there has been no dialogue with persons involved in career guidance. It means that there is a need for systematic pedagogical and career support, in order to clarify with students' learning goals and motivation. Research data show that students are most likely to trust their school and group members $(20.7 \%)$, group' teachers $(20.5 \%)$, subject teachers $(15.8 \%)$ and teachers of practical works $(13.8 \%)$, but the least - to practice teachers at enterprise $(5.1 \%)$, school management $(6.8 \%)$ and career counsellors $(7.5 \%)$. So, a weakest dialogical link is with persons, who have the task of coordinating long-term collaboration in students' career guidance (Killeen, Kidd, 2005) and developing recently started work-based learning (Procedures by which..., 2016).

Exploring the nature of W. Isaacs fields of conversations, it can be recognized that such development of dialogue has been observed in any educational situation - whether it be a lesson or practice, or any other training episode in which the students takes on new and/or repeats the acquired knowledge and skills, they may be surprised by the expansion of new knowledge, going deeper into case studies. It is not even important in which year the student is studying, but his experience is another that helps to make a more meaningful understanding of his career development and life designing. Such development and achievement of the goals of dialogue is possible in work-based learning, which is gradually being implemented in Latvia vocational secondary education since 2013/2014 (ESF projekts..., 2019). It involves four stakeholders - learners, entrepreneurs, vocational education establishments and the Latvia government (Vjakse, 2019) to develop mutual cooperation and dialogue. Number of benefits can be expected from such a dialogue. For example, students have the opportunity to acquire a profession in the real workplace and 
knowledge according to the latest trends in the industry. In turn, entrepreneurs get to know the student and assess his compliance with profession and enterprise. Vocational education establishments are starting to develop curricula in collaboration with enterprises, in line with labour market requirements; to identify those students who are not interested in acquiring the concerned profession and seek the opportunity to offer them other education programs. But the Latvia state acquires the formation of an education system focused on adapting the skills and interests of each student to the labour market. This saves essential resources in a timely manner by identifying career aspirations and opportunities by channelling the young person to the career stage that is most suitable for him. Thus, it can be assumed that work-based learning could be a secured basis for systematic students' career guidance, involving responsible persons - teachers, school leaders, and school collaborators. Creating this kind of mutual cooperation will help to reveal how open the student and other responsible persons of career guidance are to make a dialogue.

Therefore, the goals of dialogue should be assessed in the context of career guidance of vocational secondary education (Karjeras izglìtība profesionālās..., 2006) (Figure 1). In the first phase "Career Guidance and Counselling before Enrolment" takes young people providing with the necessary information about opportunities to acquire the chosen profession. It means that the information available can be perceived in a variety of ways, as well as being located and operating in an environment where this information is located. In this way, young people will make sure that joining and learning in relevant vocational education institution will ensure their expectations of acquiring professional qualifications and career opportunities (Karjeras izglîtība profesionālās..., 2006). So, the goal of the dialogue at this stage is to obtain assurance about the right career choices.

In the second stage, "Career Guidance at the Start of the Learning Process" focuses mainly on the adaptation of first-year students to new learning and life situation, so that they understand their learning motivation as well as learn about the specifics of the chosen profession (Karjeras izglititiba profesionālās..., 2006) (Figure 1). Successfully organized measures of career guidance during the adaptation period ensure the harmonious development of the students' personality. Therefore, the goal of the dialogue is self-knowledge and mutual communication in a new learning environment. Self-knowledge is necessary to make decisions about further career choices. Finding himself, the student is easier to select career-related information and evaluate what is suitable for them. This information at the later stages of career guidance will help to identify career alternatives and will be useful in different stages of professional life transitions.

In the third stage, "Career Guidance during the Learning Process", career development opportunities are selected in the chosen professional sector. It is important for students to provide information about the world of work; to acquaint with the labour law and standard requirements in the chosen professions; motivate to create or continue to supplement own portfolio as well as to promote the willingness to make independent decisions in the planning and management of the chosen career. It is very important to ensure the availability of groups and individual counselling, in order to solve personal and social problems as well as problems of learning (Karjeras izglìtība profesionālās..., 2006). Therefore, the goal of dialogue is to purposefully explore, ask and weigh in order to better understand own career planning opportunities. In the fourth stage "Preparing for Transition from Education to the Labour Market" is related to practical training and practice in the workplace where potential employers help to understand the demands of the industry (Karjeras izglītîba profesionālās..., 2006). At this stage, students develop job searching skills that include communication skills, applied drafting skills and ability to work with information sources. It follows that the goal of the dialogue is mutual cooperation between schools and entrepreneurship in which all parties to form a common understanding of the relevant security placements where students can successfully perform training tasks and gain useful skills of their professional qualification.

The fifth stage of the "Cooperation with Alumni" refers to the fact that students' cooperation with vocational secondary education establishments after graduation does not end, but to move to another level. They become a school' collaboration partners from the industrial sector or colleagues, who are working in vocational education. As representatives of the industry, they are invited to participate in the implementation of the educational content - they meet with students in career guidance activities; becoming entrepreneurs, they run student practices; assesses students' professional competencies in qualification examinations; provides recommendations for improving educational content, etc. (Karjeras izglìtība profesionālās..., 2006). Therefore, the goal of the dialogue is linked to the goal of the upstream dialogue, but the goal should be based on work-based learning in sustainability. 
The stated goals of the dialogue at all the above-mentioned stages of career guidance are achievable by providing career information, education, and counselling, thus facilitating the choice and acquisition of profession corresponding to the student's abilities and interests, as well as developing the competence to independently manage own career.

\section{Conclusions}

- The obtained theoretical and empirical findings suggest that meaningful dialogue in students' career guidance of vocational secondary education contributes to the formation of common understanding and coordinated actions among the persons involved in dialogue with a point to find the best solutions for career planning and life designing of the students.

- The defining of dialogue goals of students' career guidance in vocational secondary education shows that it is a complex set of activities involving persons from both the educational and the business environment. For lunch, it is a long-lasting process, starting with the support of applicants and ending with collaboration with schools' graduates. Therefore, goals of dialogue have a hierarchical and successive nature. Such goal-setting points to the quality of the dialogue - how mutual co-operation and a common understanding of students' career and life planning have developed.

- Focused dialogue in students' career guidance teaches stakeholders to understand each other and to see a broader and clearer range of career issues. This would be difficult to achieve if career issues were addressed by the students themselves or by a small number of persons who are involved in the organization of career guidance.

- Achieving the goals of dialogue in students' career guidance of vocational secondary education gives two persistent benefits for all - firstly, students are aware and understand that engaging in dialogue helps to cope with learning and self-awareness as well as researching of labour market with a purpose to understand how to plan their career in the chosen profession. Secondly, the responsible involved persons - teachers, school management and stakeholders - will see the point of investing their time and resources in the education of young professionals.

\section{Bibliography}

1. Bohm D. (2004). On dialogue ( $2^{\text {nd }}$ ed.). New York: Routledge.

2. Doran G.T. (1981). There's a S.M.A.R.T. Way to Write Management's Goals and Objectives. Management Review, 70(11), 35-36. Retrieved from https://community.mis.temple.edu/mis0855 002fall2015/files/2015/10/S.M.A.R.T-Way-Management-Review.pdf

3. ESF projekts «Profesionālo izglìtības iestāău audzēknnu dalība darba vidē balstītās mācībās un mācību praksēs uzñēmumos» Nr. 8.5.1.0/16/I/001 atbilstoši SAM 8.5.1. [ESF project «Participation of vocational education students in work-based learning and training practices in enterprises» Nr. 8.5.1.0/16/I/001 according to SAM 8.5.1.]. (2019). Retrieved from http://www.lddk.lv/projekts /darba-vide-balstitas-macibas/ (in Latvian)

4. Habermas J. (2015). Communication and the Evolution of Society. Hoboken: John Wiley \& Sons.

5. Hitchcock D., Mcburney P., Parsons S. (2001). A framework for deliberation dialogues. In H.V. Hansen, R.C. Pinto, C.W. Tindale, J.A. Blair, R.H. Johnson (Eds.), Proceedings of the Ontario Society for the Study of Argumentation Conference Argumentation and its Applications, 4. Retrieved from https://scholar.uwindsor.ca/cgi/viewcontent.cgi?article $=1642 \&$ context=ossaarchive

6. Isaacs W. (1999). Dialogue and the Art of Thinking Together: A Pioneering Approach to Communicating in Business and in Life. New York: Crown Business.

7. Karjeras izglìtība profesionālās vidējās izglìtības iestādēs. Skolotāja rokasgrāmata [Career education in vocational secondary education institutions. Teacher's Guide]. (2006). Rīga: Profesionālās izglīî̄bas attīstības aǵentūra. Retrieved from http://viaa.gov.lv/files/news/722/prof _karjeras_izgl_rokasgr_skolot.pdf (in Latvian)

8. Killeen J., Kidd J.M. (2005). The Career Service. In A.G Watts, B. Law, J. Killeen, J.M. Kidd, R. Hawthorn (Eds.), Rethinking Careers Education and Guidance: Theory, Policy and Practice. London and New York: Routledge, 99-109. 
9. London S. (2005). The Power of Deliberative Dialogue. In R.J. Kingston (Ed.), Public Thought and Foreign Policy: Essays on Public Deliberations about Americans' Role in the World. Dayton: Kettering Foundation Press, 85-102.

10. Peavy R.V. (2004). Sociodynamic Counselling: A Practical Approach to Meaning Making. Chagrin Falls: Taos Institute Publications.

11. Pedagoǵijas terminu skaidrojošā vārdnīca [Glossary of pedagogical terms]. (2000). Rīga: Zvaigzne ABC. (in Latvian)

12. Procedures by which Work-based Learning is Organised and Implemented. (2016). Rìga: Republic of Latvia, Cabinet of Ministers, Regulation No. 484. Retrieved from https://likumi.lv/ta/en/en/id/283680

13. Racene A., Dislere V. (2019). Choice of a Value Identification Method in Career Counselling. In V. Dislere (Ed.), the Proceedings of the International Scientific Conference Rural Environment. Education. Personality (REEP), 12. Jelgava: Latvia University of Life Sciences and Technologies, 289-296. doi: 10.22616/REEP.2019.038

14. Scharmer C.O. (2016). Theory U: Leading from the Future as it Emerges. Oakland: BerrettKoehler Publishers.

15. Senge P.M. (2006). The Fifth Discipline: The Art and Practice of the Learning Organization. New York: Doubleday.

16. Traum D.R., Allen J.F. (1992). A "Speech Acts" Approach to Grounding in Conversation. In J.J. Ohala, T.M. Nearey, B.L. Derwing, M.M. Hodge, G.E. Wiebe (Eds.), ICSLP 92 Proceedings: 1992 International Conference on Spoken Language Processing, Edmonton: Priority Printing, 137140. Retrieved from https://www.isca-speech.org/archive/archive_papers/icslp_1992/i92_0137.pdf

17. Vjakse J. (2019). Darba vidē balstītas mācības [Work based training]. Retrieved from https://viaa.gov.lv/library/files/original/DARBA_VIDE_BALSTITAS_MACIBAS_DVB.pdf (in Latvian)

18. Walton D.N., Krabbe E.C.W. (1995). Commitment in Dialogue: Basic Concepts of Interpersonal Reasoning. Albany: State University of New York Press. 